\title{
ANALYSIS ON THE PREPARATION OF INTERNATIONAL STANDARD IMPLEMENTATION TO INDONESIA AUTOMOTIVE INDUSTRY EXPECTED PERFORMANCE FACING ASEAN ECONOMIC COMMUNITY 2015
}

\author{
Muhammad Ikhsan, Nila K. Hidayat, Linus Pasasa \\ muhammad.ikhsan@gmx.de, nila.hidayat@sgu.ac.id, linus.pasasa@sgu.ac.id \\ Management Study Program - Swiss German University
}

\begin{abstract}
This is largely due to the substantial range of networking and interconnectivity brought on by the positive surge of development in global trade that enables companies to expand their business overseas and reach out to more than just domestic markets scene. The ASEAN Economic Community 2015 is a challenge to make a single barrier free market all through of the 10 (ten) member countries, devoid of barriers its services, capital, and allowing goods, and skilled labor to move freely across borders. ASEAN Member States are agreed to implementing UNECE Wp. 29 for to be a basis harmonization automotive technical regulation in ASEAN region. The purpose of this thesis is to measure a correlation between UNECE International Automotive Standard and The Indonesia Automotive Industry (expected) performance. As a result it has been concluded that correlations between UNECE International Automotive Standard and Indonesia Automotive Industry performance does exists. Implementing UNECE International Standard bring technologies, economic and social benefits into the country and the manufacturing and it will helps to contribute an improvement in Automotive Industry in Indonesia. Process documentation and control is the major influence towards improving the performance of Automotive Industry in Indonesia and Supplier Related Benefits is the factor that gives a significant influence for improvement Indonesia Automotive Industry performance.
\end{abstract}

Keywords : AEC 2015, UNECE International Automotive Standard, ASEAN MRA, Indonesia Automotive Industry.

\section{INTRODUCTION}

In conjunction with the globalization in the automotive industry, it is required international harmonization of technical requirements for motor vehicles. The goals are reducing the cost and time of development of the automotive industry and avoid a repeat of an administrative procedure in the national automotive industry.

ASEAN has three top automotive producers: Thailand, Malaysia, and Indonesia, and all used an advantage of the government schemes to promote prosperous automotive industry and that report for $90 \%$ of motor vehicle output (passenger vehicles and truck) in ASEAN. 


\begin{tabular}{|c|c|c|c|c|}
\hline \multicolumn{5}{|c|}{ PRODUCTION OF MOTOR VEHICLES } \\
\hline Country & \multicolumn{2}{|c|}{2011} & 2012 & $\begin{array}{l}2013 \text { January - } \\
\text { November }\end{array}$ \\
\hline Thailand & \multicolumn{2}{|c|}{$1.457,795$} & 2.453,717 & $2.298,193$ \\
\hline Indonesia & \multicolumn{2}{|c|}{837.948} & $1.065,557$ & $1.113,555$ \\
\hline Malaysia & \multicolumn{2}{|c|}{$\mathbf{5 3 3 . 5 1 5}$} & 569.620 & 548.420 \\
\hline \multicolumn{5}{|c|}{ SALES OF MOTOR VEHICLES } \\
\hline Country & 2011 & 2012 & & $\begin{array}{l}2013 \\
\text { January - November }\end{array}$ \\
\hline Thailand & 794,081 & $1,436,335$ & & $1,216,751$ \\
\hline Indonesia & 894,164 & $1,116,212$ & & $1,132,174$ \\
\hline Malaysia & 600,123 & 627,753 & & 595,300 \\
\hline
\end{tabular}

Table 1 ASEAN Top Three Automotive Production and Sales Source: ASEAN Automotive Federation (AAF)

All of ASEAN members have agreed to achieve economic integration by establishing the ASEAN Economic Community (AEC), including for automotive sector. The establishment of AEC is intended as a means to enhance the competitiveness of the ASEAN region, to boost economic growth, to reduce poverty and to improve the living standard of the ASEAN countries (Sosesatro, 2008).

ASEAN Member States have agreed that UN Regulations set up in the UNECE 1958 Agreement should be the basis for the harmonization of technical regulations for automotive products in the region. The ASEAN Mutual Recognition Agreement provide a mutual frame of recognition for the conformity assessment results (testing, inspection and certification) of the 19 automotive systems that divided by two, which are 14 regulations for automobile and 5 regulations for motorcycle systems (EIBD, 2012).

Indonesian automotive industry has SNI (Standar Nasional Indonesia) as their based technical regulation for domestic product. In this case, SNI already adopt some international standard for the product, but is not $100 \%$ (a hundred percent) complying with UNECE international standard for automotive. To make Indonesia automotive industry competitive in the region facing ASEAN Economic Community 2015, they should make UNECE international automotive standard as a basis technical regulation in the region. Indonesia automotive industry has not implementing full international standard yet for their technical regulation, thus in this study the researcher analyzes the impact by implementing full standardization to the expected performance of Indonesia automotive industry. 


\section{LITERATURE REVIEW AND HYPOTHESIS}

\section{Globalization}

At the present time, there are vast opportunities for business expansion especially overseas. This is largely due to the substantial range of networking and interconnectivity brought on by the positive surge of development in global trade that enables companies to expand their business overseas and reach out to more than just domestic markets scene. As mentioned before in literature review, since early 1990s there has been a significant increase in global strategy and organization as so many different issues has been addressed in a range of perspectives resulting in various methods of keeping up with global competitive market, and also develop the general understanding of the intrigue of competing in global market.

No clear definition exists to what defines the Internationalization process (Fillis, 2001) gives a broad definition about the Internationalization process as explained; "Internationalization is a continuous process of choice between policies which differ maybe only marginally from the status quo. It is perhaps best conceptualizes in terms of the learning curve theory. Certain stimuli tempt a firm to shift to a higher export phase, the experience (or learning) that is gained then modifies the firm's insights, prospects and indeed managerial capacity and competence. ); and new stimuli then induce the firm to move to the next higher export stage, and so on" (Cunningham and Homse, 1982; cited by Ajdari, 2007; p. 3).

Other opinions posit that globalization goes together with an internationalization concept and the core question is whether the firm should internationalize its activities along a variety of dimensions including where it sells its products or services, where it produces these products or services, where it outsources key inputs and where it obtains the know-how or technology to produce these products or services (Lessard, D. 2003).

\section{ASEAN Economic Community 2015}

The ASEAN Economic Community 2015 is a challenge to make a single barrier free market all through of the 10 member countries, devoid of barriers its services, capital, and allowing goods, and skilled labor to move freely across borders. Although ASEAN as a whole will likely benefit from becoming a single, fully integrated economy, the definition and means of achieving it have not been clearly defined (Lloyd 2005; Hew and Soesastro 2003).

The ASEAN Economic Community Blueprint, established to fast - track the ASEAN Economic Community (AEC) establishment by 2015, envisioned ASEAN as a highly competitive region, fully integrated into the global economy, possessing a single market production base, and characterized by equitable economic development (Goh, 2008).

The ASEAN Leaders at their Summit in Kuala Lumpur in December 1997 decided to transform ASEAN into a stable, prosperous, and highly competitive region with equitable economic development, and to reduce poverty and socio-economic disparities (ASEAN Vision 2020). At the Bali Summit in October 2003, ASEAN Leaders declared that the ASEAN Economic Community (AEC) shall be the goal of regional economic integration (Bali Concord II) by 2020. In addition to the AEC, the ASEAN Security Community and the ASEAN Socio-Cultural Community are the other two integral pillars of the envisaged ASEAN Community. All the three pillars are expected to work in tandem in establishing the ASEAN Community in 2020 (ASEAN Economic Blueprint).

According to Soesastro (2008), The idea of a single market and production base is essentially about providing consumers in the region with an expended market from which they can fulfill their consumption needs and producers in the region with an expended space in which they 
can undertake their production activities without having to worry about national (administrative) boundaries in the region.

The AEC meant to be a single market and production base, with a free movement of goods, services, investment, skilled labor and free flow of capital. The AEC should also foster equitable economic development in the region and reduce poverty and socio-economic disparities by the year 2020 (ASEAN Secretariat, 2007).

\section{ASEAN Mutual Recognition Agreement}

MRA is an agreement from all ASEAN countries to mutually recognize or accept some or all aspects of the assessment results such as test results or certificates (Soesastro, 2008).

Through MRAs, products that are tested and certified before export can enter the importing country directly without having to undergo similar conformity assessment procedures in the importing country. With the increasing importance of standardization and conformity assessment in international trade, MRAs have emerged as a key strategy to facilitate trade by reducing the need for multiple testing and certification that incur unnecessary costs to exports and delay delivery to market (MRA Framework Agreement).

ASEAN Mutual Recognition Arrangement identify for conformity assessment activities could be an important means of eliminating Technical Barriers to Trade and enhancing market access and that such mutual recognition could be of particular interest to small and medium-sized businesses in ASEAN and MRAs could contribute positively in encouraging greater international harmonization of standards and regulations and that any such MRAs would require confidence in the other Member States' capacity and competence to test or assess conformity to a Member State's own requirements.

The harmonization of automotive product standards is essential as basis for a single manufacturing base. As work has begun within ASEAN on the alignment of technical requirements, 50 UNECE regulations have been identified where 19 of those have been prioritized and will form part of the Mutual Recognition Arrangement (MRA) for automotive products in ASEAN. This research has limitation from 19 UNECE regulations to be only focused on 14 regulations for 4-wheels components. This are the list of 14 regulations will adopt by ASEAN Member States by UNECE:

\begin{tabular}{|ll|}
\hline ITEM & NEEDED \\
R13 & Series 11 (Braking system) \\
R13H & Series 00 (Braking for passenger car) \\
R14 & Series 06 (Seatbelt anchorage) \\
R16 & Series 06 (Seatbelt) \\
R17 & Series 07 (Seat) \\
R25 & Series 04 (Head restraint) \\
R30 & Series 05 (Pneumatic tyre - passenger) \\
R43 & Series 02 (Safety glass) \\
R46 & Series 02 (Rear - view mirror) \\
\hline
\end{tabular}




\begin{tabular}{|ll|}
\hline R49 & Series 05 (Emission for heavy vehicle) \\
R51 & Series 02 (Noise emission at least 4 - wheel) \\
R54 & Series 00 (Pneumatic tyre - commercial) \\
R79 & (Steering Equipment) \\
R83 & (Emission for light vehivle) \\
\hline
\end{tabular}

\section{International Standard Organization}

To facilitate the international coordination and unification of industrial standards" was the primary reason behind the meetings between delegates from 25 countries that took place at the Institute of Civil Engineers in London in 1946. Short of a year later, the new organisation ISO was officially up-and-running.

More than 19,500 international standards have been published since then, standards that cover virtually all of technology and manufacturing aspects that has been taken care of by members from 164 countries and 3,368 technical bodies from all around the world and accommodated by over 150 full-time workers in the ISO's headquarter in Geneva, Switzerland.

Ensuring safe, reliable, environmentally friendly and good quality products and services is the primary intentions of the ISO international standards. These standards may also be considered as strategic tools to achieving efficient process and in the way also minimize errors and waste, and ultimately reducing costs for businesses, and increasing productivity. Furthermore, these international standards will be of a great help in facilitating free and fair global trade by accommodating companies to access new markets, and level the playing field for companies and businesses from developing countries.

International Standards bring technological, economic and societal benefits. They help to harmonize technical specifications of products and services making industry more efficient and breaking down barriers to international trade. Conformity to International Standards helps reassure consumers that products are safe, efficient and good for the environment.

International Standards are strategic tools and guidelines to help companies tackle some of the most demanding challenges of modern business. They ensure that business operations are as efficient as possible, increase productivity and help company access new markets. The benefits includes: cost savings, enhanced customer satisfaction, access to new markets, increased market share, environmental benefits.

\section{Industrial Organizational Theory}

Coming back to the global strategy it is needed to mention that according to Zou and Cavusgil (1996) the literature regarding global strategy is mainly dominated by the industrial organization (IO) perspective (Bartlett and Ghoshal, 1991).

While the IO approach has enriched understanding of the external market and industry forces which drive globalization, it generally has neglected a business's idiosyncratic internal characteristics (Bartlett and Ghoshal, 1991). It means that business performance is not solely determined by global strategy and that internal organizational characteristics also play an important role. As a result, domination by the IO perspective can lead to incomplete explanation of global strategy and performance.

In the IO-based model, competitive advantage is viewed as a position of superior performance that a business attains through offering undifferentiated products at low prices or 
offering differentiated products for which customers are willing to pay a price premium (see Porter, 1980).

It can be said that Porter $(1980 ; 1985)$ made the most influential contribution to the field employing IO economics. Using a structural analysis approach, (Porter, 1980) outlines an analytical framework that can be used in understanding the structure of an industry. (Porter, $1980 ; 1985$ ) suggested generic strategies (low cost leadership, differentiation, and focus) that can be used to match particular industry foci and, thereby, build competitive advantage (cited in Hoskisson, Hitt, Wan, \&Yiu, 1999).

\section{United Nations Economic Commissions for Europe Working Parties 29 (ENECE Wp.} 29)

One of the five United Nations' regional commissions is the United Nation Economic Commissions for Europe (UNECE) was formed in 1947. Environmental policy, Inland transport, Sustainable energy, European statisticians, Trade, Timber, Housing and land management, Economic cooperation and integration are the areas that is covered by the expertise of UNECE that comprises 56 countries in Europe, North America, Regions of Caucasus, and Central Asia.

Resolution No. 45 of the Subcommittee on Road Transport (SC.1) of the Economic Commission for Europe of the United Nations (UNECE) established World Forum for Harmonization of Vehicle Regulations (WP.29), which previously known as the Working Party on the Construction of Vehicles. In order to instigate the general technical provisions set in the Convention on Road Traffic adopted in Geneva in 1949, the resolution called for the establishment of a working party of experts competent in the field of technical requirements for vehicles, and in the end, those provisions identified vehicle characteristics as a major cause of road traffic crashes, deaths and injuries.

The United Nations Economic Commission for Europe (UNECE) envisioned to eliminate technical barriers to the trade in motor vehicles internationally, and subsequently develops harmonized requirements for the systems used for motor vehicles between the Contracting Parties to the Revised 1958 Agreement and ensuring that such vehicles and systems offer a high level of safety and environmental protection.

\section{Generic Strategy}

Michael Porter (1980) detailed the three generic strategies available to a firm: cost leadership, differentiation, and focus strategies. Firms must make a choice if the firm is to attain a competitive advantage vis-à-vis its rivals. Modern manufacturing systems and technologies support global mass customization, which in turn supports the strategic position the firm has chosen. The key is to align business process with customers' need using mass customization (Salvador, Martin de Holan, and Piller, 2009).

Generic strategy is a core idea about how a firm can best compete in the marketplace. From a scheme developed by Michael Porter, many planners believe that any long term strategy should derive from a firm's attempt to seek a competitive advantage based on one of three generic strategies:

a. Striving for overall low-cost leadership in the industry. Low-cost leaders depend on some fairly unique capabilities to achieve and sustain their low-cost position. Examples of such capabilities are having secured suppliers of scarce raw materials, being in a dominant market share position, or having a high degree of capitalization. Low-cost leadership are maximize economies of scale, implement cost-cutting technologies, stress reductions in 
overhead and in administrative expenses, and use volume sales technique to propel themselves up the earning curve.

b. Striving to create and market unique products for varied customer groups through differentiation. Strategies dependent on differentiation are designed to appeal to customers with a special sensitivity for a particular product attribute. By stressing the attribute above other product qualities, the firm attempts to build customer loyalty. The product attribute also can be the marketing channels through which it is delivered, its image for excellence, the features it includes, and the service network that supports it.

c. Striving to have special appeal to one or more groups of consumer or industrial buyers, focusing on their cost or differentiation concerns. A focus strategy, whether anchored in a low-cost base or a differentiation base, attempts to attend to the needs of a particular market segment. Likely segments are those that are ignored by marketing appeals to easily accessible markets, to the "typical" customer, or to customers with common applications for the product. A firm pursuing a focus strategy is willing to service isolated geographic areas; to satisfy the needs of customers with special financing, inventory, or servicing problems; or to tailor the product to the somewhat unique demands of the smallto medium-sized customer.

\section{HYPHOTHESIS}

Hypothesis 1: There is a correlation between International Automotive Standard implementation dimensions and Indonesian Automotive Industry (expected) performance parameters.

Hypothesis 2: Continuous improvement is the major significant influence of UNECE International Standard implementation dimensions.

Hypothesis 3: Business related benefits are the major significant influence of Indonesia Automotive Industry (expected) performance parameters.

\section{RESEARCH METHODOLOGY}

This study conducted in 30 medium to large scale automotive manufacturing companies in Indonesia which is in the midst of implementing UNECE international standard.

Primary and secondary data are gathered from various sources. Questionnaire and interviews from Indonesia Automotive Industry while keeping the focus on braking system are the method by which the primary data are gathered with the intention to determine the obstacles of the preparation of implementing International Automotive Standard (UNECE Wp. 29) based on ASEAN MRA Agreement for facing ASEAN Economic Community 2015.

A sampling method is used to collect the data. The sampling method selected only a handful part of the population to represent the whole population. In this case, the survey was conducted with the help of 30 manufacturing companies that are members of GAIKINDO (Gabungan Industri Kendaraan Bermotor Indonesia or Association of Indonesian Automotive Industry). 


\begin{tabular}{|l|l|}
\hline Data & \\
\hline $\begin{array}{l}\text { Estimate of True } \\
\text { Proportion }\end{array}$ & 0.9 \\
\hline Sampling Error & 0.05 \\
\hline Confidence Level & $95 \%$ \\
\hline
\end{tabular}

\begin{tabular}{|l|l|}
\hline \multicolumn{2}{|l|}{ Intermediate Calculations } \\
\hline Z Value & -1.9600 \\
\hline Calculated Sample Size & 138.2925 \\
\hline
\end{tabular}

\begin{tabular}{|l|l|}
\hline Result \\
\hline Sample Size Needed & 139 \\
\hline
\end{tabular}

\begin{tabular}{|l|l|}
\hline Finite Populations & \\
\hline Population Size & $\mathbf{3 7}$ \\
\hline Calculated Sample Size & 29.3577 \\
\hline Sample Size Needed & $\mathbf{3 0}$ \\
\hline
\end{tabular}

The result from the questionnaire helps to recognize the success factor for the international standard implementation in Indonesian automotive standard particularly on the safety system implementation manufacturing industry. Member companies of GAIKINDO and random samplings from randomly researcher-selected companies with better possibility of relation with the study are the samples from which the survey is conducted, and with the members of GAIKINDO, the interview was performed several times in order to gather the qualitative information required to understand the research issues better.

In this research the research using Structural Equation Modelling (SEM) for analyze the data because the model needs more data and have a high level of complexity. Structural Equation Modelling (SEM) is a statistical technique using a combination of statistical data for testing and estimating causal relationships between observed (measured) and unobserved (latent) variables, and also the relationship between two or more variables (Burns \& Bush, 2006).

To demonstrate the relationship between observed and unobserved variables, and also the define the interconnections between the two, examiners used the path diagram as a SEM tool. The visual model and the way that the hypotheses are connected to the problem can be explained by the diagram. The path diagram in this research is constructed by using AMOS Software (Analysis of Moment Structures). The correlation coefficient is an index number, constrained to fall between the range of -1.0 and +1.0 that communicates both the strength and the direction of a linear relationship between two variables (Burns \& Bush, 2006). 


\section{RESULT AND DISCUSSION}

\section{Path Diagram}

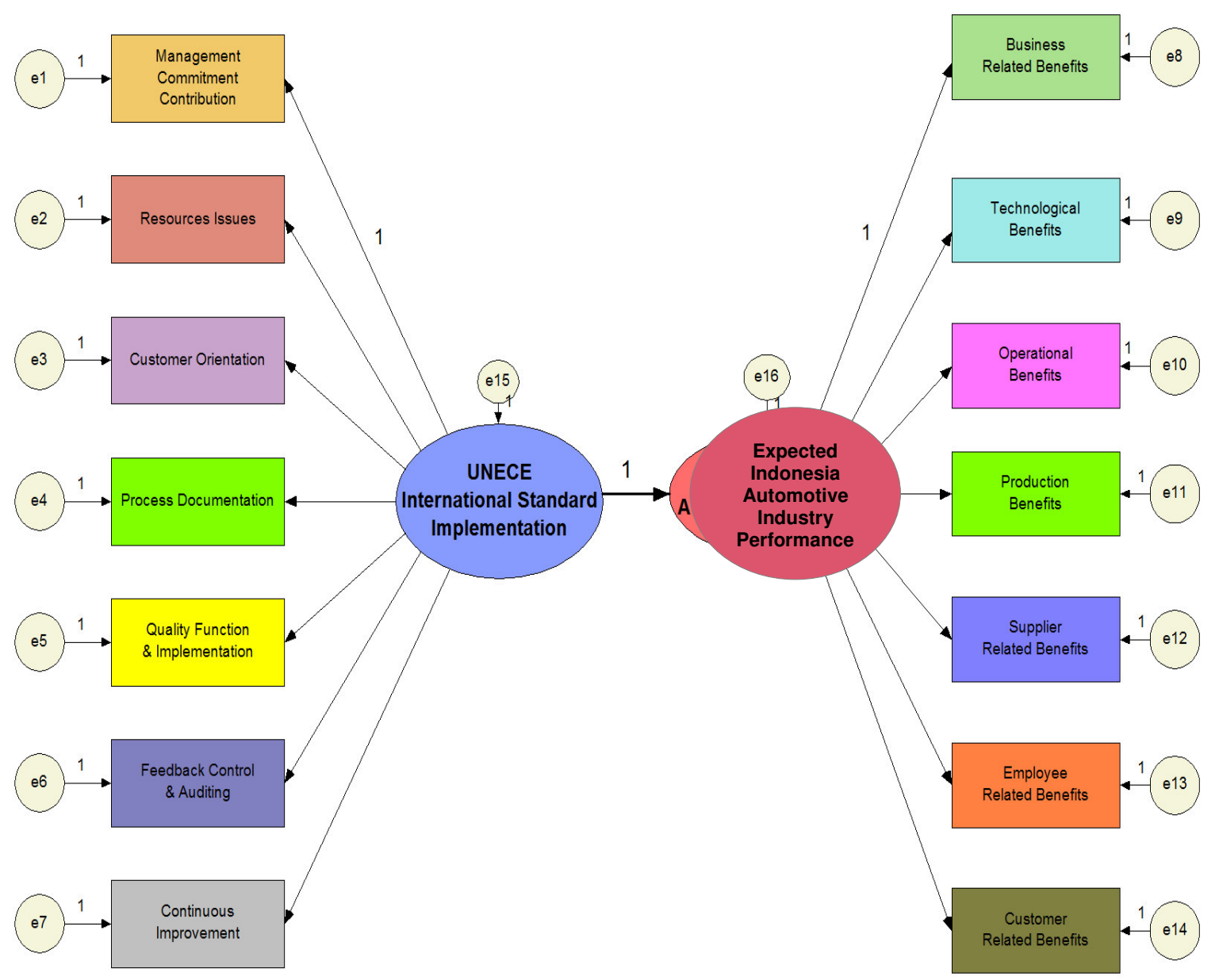

From the model above showing that there are 14 factors will influence regarding an improvement for Indonesia automotive industry by implementing UNECE international automotive standard. This study will examine the most factors from UNECE International automotive standard and also from Indonesian automotive industry will contribute towards improving for Indonesian automotive industry.

Hypothesis 1: There is a correlation between International Automotive Standard implementation dimensions and Indonesian Automotive Industry (expected) performance parameters.

\begin{tabular}{|l|l|l|l|}
\hline Factor & Correlation $\mathrm{r}$ & Correlation $\mathrm{r}^{2}$ & Association \\
\hline $\begin{array}{l}\text { UNECE International } \\
\text { Automotive Standard } \\
\text { Implementation }\end{array}$ & 0.77 & $52.29 \%$ & Moderate \\
\hline
\end{tabular}


Based on analysis using AMOS, the percentage in table above shown that UNECE International Automotive Standard have a strong correlation with Indonesia Automotive Industry with coefficient correlation 0.77 or contribute $52.29 \%$ and moderate association.

Therefore, hypothesis 1 above is accepted.

The interpretation table above that shown UNECE International Automotive Standard has a strongest correlation Indonesia Automotive Industry performance. It means that international standardization have a significant contribution on improvement Indonesia Automotive Industry performance.

Hypothesis 2: Continuous improvement is the major significant influence of UNECE International Standard implementation dimensions.

\begin{tabular}{|l|l|l|l|}
\hline Factor & Correlation $\mathrm{r}$ & Correlation $^{2}$ & Association \\
\hline $\begin{array}{l}\text { Continuous } \\
\text { improvement }\end{array}$ & 0.60 & $36.00 \%$ & Moderate \\
\hline
\end{tabular}

Based on analysis using AMOS, the percentage in table above shown that continuous improvement is not a strongest influence of UNECE International Automotive Standard with coefficient correlation 0.60 or contribute $36.00 \%$ and of moderate association.

Therefore, hypothesis 2 above is rejected.

The interpretation of table above, showing that continuous improvement factor is not significantly influence UNECE International Automotive Standard on contributing to improve Indonesia Automotive Industry performance.

Hypothesis 3: Business related benefits are the major significant influence of Indonesia Automotive Industry parameters.

\begin{tabular}{|l|l|l|l|}
\hline Factor & Correlation $\mathrm{r}$ & Correlation $\mathrm{r}^{2}$ & Association \\
\hline $\begin{array}{l}\text { Business related } \\
\text { benefits }\end{array}$ & 0.67 & $44.89 \%$ & Moderate \\
\hline
\end{tabular}

Based on analysis using AMOS, the percentage in table above shown that business related benefits factor is not a strongest correlation with coefficient correlation 0.67 or contribute $44.89 \%$ and moderate association. Therefore, hypothesis 3 above is rejected.

The interpretation of table above that shows business related benefits is not a strongest correlation on implementing UNECE International Automotive Standard. In this research that business related benefits is not significantly improved by implementing UNECE International Standard.

\section{Analysis of implementing the International Automotive Standard for the Indonesia Automotive Industry}

Benefits in economy, technology, and society are just some of the advantage that international standard can bring into any industry. Compliance to international standard may help to synchronise technical specifications of any products and services and therefore 
removing any trade barriers, which will eventually makes the industry more effective and consumers are encouraged to think that the products are safe and environmentally friendly because it has passed the international standard, of which will ultimately resulting in increased customer satisfaction and sales.

Supported by some facts and result from the questionnaire, below are the researcher's analyses of the benefits of implementing International Standard for Indonesia Automotive Industry for facing ASEAN Economic Community 2015.

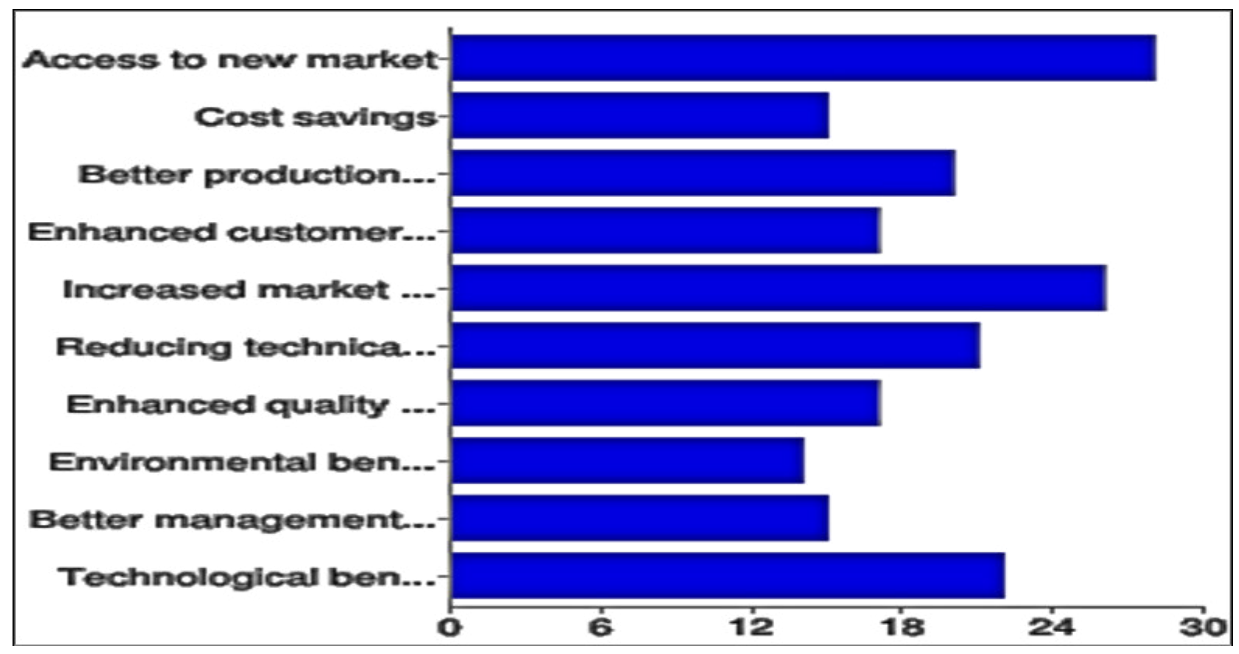

Figure above shows that the most profitable benefit nominated by Indonesian automotive companies in Indonesia is the ability to access new market or make the companies itself to be ready more globally, and it supposed to be chance for Indonesian automotive companies to increase their market share.

The other benefits are by implementing international standard would be enhanced quality and customer satisfaction, because nowadays the customer awareness about quality of safety is increased following many traffic accidents. By implementing International Standard the exporter could be reduce their cost of doing process fit and proper test in destination export country. This process is rather expensive and could be entirely eliminated if Indonesia implements the international standards, and could ultimately be highly profitable in terms of cutting the cost for the companies because the companies do not need to perform those tests before exporting anymore.

\section{Economic Implication of UNECE International Standard Implementation to the Indonesian's automotive industry}

Even Indonesia is still based on SNI (Standard National Indonesia) but the roadmap to implement UNECE as international standard will bring a great benefits including economic implication. The International Standard will make Indonesia automotive industry competitive in the region facing ASEAN Economic Community 2015. Thus, it relates with the increasing volumes of export. The manufacture will gain a potential access to new global market and as well reducing any technical trade barriers. Technical barriers for each country it would be different because each government apply different technical requirements to protect their domestic market. Implementing international standard also will bring new technological 
benefits for Indonesian domestic production and it would definitely be an advantage for Indonesian Industry.

\section{Conclusion}

To achieve the goals of ASEAN Economic Community, ASEAN Member States should liberalize trade in goods, service, investment, and labor. ASEAN Mutual Recognition Arrangement (MRA) is one of several ASEAN mechanisms to facilitate trade liberalization. To facilitate the liberalization of trade in ASEAN Region, the main efforts is to harmonize standard of existing as well as on trade in goods. The ASEAN Member States have agreed that the UNECE International Standard especially in Wp. 29 for Automotive Standard should be the basis for harmonization of the automotive technical regulation in ASEAN. In the agreement there are 14 standards that should be harmonized for the ASEAN Member States, but in this research only focus on safety system.

The findings of this research are there strong correlations between UNECE International Standard and Expected Indonesia Automotive Industry Performance. The result from statistical method shows that UNECE International Standard will enhance Indonesia Automotive Industry performance. There are 7 factors will influence UNECE International Standard on affecting Indonesia Automotive Industry performance parameters, such as: management commitment, resources issues, customer orientation, process documentation and control, quality function, feed-back control and auditing, and continuous improvement. From this validates shown that process documentation and control has a biggest impact for the Indonesia Automotive Industry for enhancing company performance.

From the Indonesia Automotive Industry side, there are 7 factors as an indicator for performance parameters such as: business related benefits, technological benefits, operational benefits, production benefits, supplier related benefits, employee related benefits, customer related benefits. This validates shown that supplier related benefits are the major factors would be affected on implementing UNECE International Standard. Supplier related benefits can effectively contribute for the Indonesia Automotive Industry in realization implementing UNECE International Standard.

There are many benefits for Indonesia Automotive Industry on implementing UNECE International Standard. Based on the questionnaire results include an open answer question, this research reveals that the main benefits for the manufacturing companies are prepared them into global market and it supposed to be chance for Indonesia Automotive Industry for increase market share. To support manufacturing companies ready for global, implementing international standard also helping to reduce trade barriers. Implementation international standard will reduce cost of doing proper and test because the manufacturing company already fulfil the requirement standard for global. There are many benefits for manufacturing companies if implementing International Standard. The findings suggest that effective of UNECE International Standard implementation can significantly contribute towards realization of strategic manufacturing performance improvement for competing in the highly dynamic global market place. 
Muhammad Ikhsan

Nila K. Hidayat

Linus Pacasa
Jurnal Manajemen Bisnis Indonesia

Vol.1, Nomor 2, Feb 2014

\section{References}

Ajdari, B. (2007). Impact of e-commerce on internationalization of Iranian's SMEs, Master Thesis, Luleå University of Technology, Department of Business Administration and Social Sciences.

Amit, R., \& Schoemaker, P. J. H. (1993). Strategic assets and organizational rent. Strategic Management Journal, 14(1), 33-46. http://dx.doi.org/10.1002/smj.4250140105

ASEAN Economic Blueprint, www.asean.org/archive/5187-10.pdf. Accessed on $14^{\text {th }}$ November 2013)

ASEAN Secretariat. ASEAN Economic Community Blueprint. Jakarta, November 2007

Bartlett, C. and Ghoshal, S. (1991). Global strategic management: impact on the new frontiers of strategy research, Strategic Management Journal, Vol. 12, pp. 5-16

Burns, A. C., \& Bush, R. F. (2006). Marketing Research (5th Edition ed.). Pearson International Edition.

Caves, R. and Williamson, P. (1985). What is Product Differentiation, Really? The Journal of Industrial Economics (34), 1985, pp. 113132.

Collis, D.J. (1991). A resource-based analysis of global competition: the case of the bearings industry. Strategic Management Journal, Vol. 12, pp. 49-68. Revised April 18th, 2010

Cooper, D. R., \& Schindler, P. S. (2011). Business Research Methods (11th Edition ed.). McGraw Hill.

Crook, T. R., Ketchen, D. J., Combs, J. G., \& Todd, S. Y. (2008). Strategic resources and performance: a meta-analysis. Strategic Management Journal, 29(11), 1141-1154. http://dx.doi.org/10.1002/smj.703

Daft, R. (1983). Organization Theory and Design. West. New York, NY. Revised April $18^{\text {th }}$, 2010.

Fillis, I. (2001). Small firm internationalization: an investigative survey and future research directions, Management decision, Vol. 39 No. 9, pp. 767-783. Revised April 17th, 2010

Goh, C. Y. (2008). ASEAN Infrastructure Financing Mechanism: Concepts and progress. Paper presented at the ASEAN Infrastructure Financing Mechanism Conference, Kuala Lumpur, Malaysia, 10 November 2008.

Grant, R. M. (2002). Contemporary Strategy Analysis, (4th ed.). Oxford: Blackwell Publishers Inc.

Hew, D. and Soesastro, H. (2003). Realizing the ASEAN Economic Community by2020:ISEAS and ASEAN-ISIS Approaches, ASEAN Economic Bulletin, IS-EAS.

Hoskisson, Hitt, Wan \& Yiu, (1999). Theory and Research in Strategic Management: Swings of a Pendulum, Journal of Management, 25(3): 417-465.

Jain, Sanjiv Kumar; Inderpreet Singh Ahuja. (2012). An evaluation of ISO 9000 initiatives in Indian industry for enhanced manufacturing performance, http://search.proquest.com/docview/1095558499/fulltextPDF/1429AE385B83E3EE7D2/1?ac countid=48290. Accessed on November $12^{\text {th }}, 2013$.

Kogut, B. (1988). Joint ventures: theoretical and empirical perspectives. Strategic Management Journal, 9, 319-32. 
Linus Pacasa

Lessard D. (2003). Frameworks for global strategic analysis. Journal of Strategic Management Education 1, Senate hall Academic Pusblishing (1). pp. 8-10 Revised May 30th, 2010

Lloyd PJ (2005). What is a single market? An application to the case of ASEAN. ASEAN Econ Bull 22:251-265

Newbert, S. L. (2007). Empirical research on the resource based view of the firm: an assessment and suggestions for future research. Strategic Management Journal, 28(2), 121146. http://dx.doi.org/10.1002/smj.573

Newbert, S. L. (2008). Value, rareness, competitive advantage, and performance: a conceptual-level empirical investigation of the resource-based view of the firm. Strategic Management Journal, 29(7), 745-768. http://dx.doi.org/10.1002/smj.686

Pearce, J. A., \& Robinson, R. B. (2013). Strategic Management: Planning for Domestic and Global Competition (13th Edition ed.). McGraw Hill.

Porter, M. (1980). Competitive Strategy: Techniques for Analyzing Industries and Competitors. New York: Free Press.

Porter, M. E. 1985. Competitive Advantage. New York: The Free Press.

Salvador, F., Martin de Holan, P., \& Piller, F. (2009). Cracking the code of mass customization. MIT Sloan Management Review, 50(3), 71-78.

Schwandt, (1997). Qualitative Inquiry: A Dictionary of Terms Sage.

Sekaran, U., \& Bougie, R. (2009). Research Methods for Business A Skill Building Approach (5th Edition ed.). John Wiley \& Sons Ltd.

Sekaran, U., \& Bougie, R. (2012). Research Methods for Business. A Skill Building Approach. Forth Edition. John Wiley \& Sons

Soesastro, H. (2008). Implementing the ASEAN Economic Community Blueprint. The ASEAN Community: Unblocking the Roadblocks (pp.30-38). Singapore: Institute for Southeast Asian Studies.

Thee, K. W. (1990). Indonesia: Technology Transfer in the Manufacturing Industry, In Soesastro, H. and M. Pangestu (eds.), Technological Challenge in the Asia-Pacific Economy, Sydney: Allen \& Unwin.

Zikmund, W., \& Babin, B. (2012). essentials of marketing research , $5^{\text {th }}$ Ed. Ohio:Cengage Learning

Zou, S. and Cavusgil C (1996). Global strategy: a review and an integrated conceptual framework. European Journal of Marketing,Vol.30, pp. 52. Revised April 18th, 2010

Zou, S. and Cavusgil C (1996). Global strategy: a review and an integrated conceptual framework. European Journal of Marketing,Vol.30, pp. 52. Revised April 18th, 2010 


\section{Web References}

EIBD 2012 Recommendation, http://eibd-

conference.com/assets/files/Recomendation2012/EIBD\%20Recommendation\%20Book\%20C ontent $\% 20$ FINAL\%20for\%20web.pdf (Accessed on $7^{\text {th }}$ November 2013)

http://www.asean.org/news/item/asean-framework-agreement-on-mutual-recognitionarrangements (Accessed on $15^{\text {th }}$ November 2013)

http://www.asean.org/news/item/asean-vision-2020 (Accessed on $18^{\text {th }}$ November 2013)

http://www.asean.org/news/item/asean-vision-2020 (Accessed on $18^{\text {th }}$ November 2013)

http://www.iso.org/iso/home/about.htm (Accessed on $19^{\mathrm{h}}$ November 2013)

http://www.iso.org/iso/home/standards.htm (Accessed on $19^{\mathrm{h}}$ November 2013)

http://www.iso.org/iso/home/standards/benefitsofstandards.htm (Accessed on $19^{\mathrm{h}}$ November 2013)

http://www.unece.org/fileadmin/DAM/trans/main/wp29/wp29wgs/wp29gen/wp29inf/121/blu ebook.pdf (Accessed on $19^{\mathrm{h}}$ November 2013)

http://www.unece.org/trans/main/wp29/meeting_docs_wp29.html (Accessed on $19^{\mathrm{h}}$ November 2013)

United Nations Economic Commission for Europe - UNECE, http://www.unece.org/ (Accessed on $19^{\mathrm{h}}$ November 2013) 